\title{
Kajian Intertekstualitas Sampul Album 'Viva La Vida’ dari Coldplay
}

\author{
Brian Alvin Hananto \\ Program Studi Desain Komunikasi Visual, Universitas Pelita Harapan \\ brian.hananto@uph.edu
}

\begin{abstract}
Every design objects had meanings that borrowed their meanings from other texts. This understanding comes from the notion of intertextuality, in which this notion isn't absent from graphic design. This article will discuss about the design of Coldplay's 2008 'Viva La Vida' album cover design. The study for the design will be done in two ways, in a formalistic manner which elaborates the design and visual elements of the design, and also in a contextual manner which discusses the meanings that come from external texts. The study is approached with a qualitative perspective, using the artifact analysis and literature review method. The result of the study is the conclusion that 'Viva La Vida' had borrowed references from other popular texts that enriches the value of the design. The author hoped that this writing can open up new perspective on how to see graphic design objects.
\end{abstract}

Keywords: Intertextuality, Graphic Design, Visual Communication, Viva La Vida, Coldplay, Type é Image.

\section{PENDAHULUAN}

Tulisan ini merupakan sebuah pengembangan dari materi perkuliahan yang penulis lakukan untuk mata kuliah Metodologi Desain. Tulisan ini akan mencoba memberikan contoh mengenai pembahasan sebuah karya desain grafis secara sederhana. Penggunaan kata 'sederhana' disini berbicara mengenai form atau struktur visual dari karya tersebut. Pembahasan kemudian akan berlanjut membahas mengenai konten dan juga konteks dari karya tersebut.

Karya yang diambil untuk pembahasan kali ini adalah karya sampul album 'Viva La Vida' dari band Coldplay, yang dirancang oleh duo desainer Mark Tappin dan Simon Gofton pada tahun 2008 (Gofton, 2009). Album yang memiliki nama lengkap 'Viva la Vida or Death and All His Friends' ini merupakan album keempat mereka, dimana para musisi tersebut mendeskripsikan album ini sebagai "pergeseran dari hitam dan putih menuju warna”. Chris Martin, sang vokalis band tersebut juga menekankan semangat eksperimentasi yang muncul dalam musik mereka ("Viva La Vida Biography," 2008). Guy Berryman, basis Coldplay menjelaskan pada majalah Q, bahwa lagu 'Viva La Vida' sendiri menceritakan mengenai seorang raja yang kehilangan kerajaannya, dan desain sampul album mereka kali ini ingin menggambarkan hal tersebut, mengenai revolusi dan gerilya, dan hal itulah yang menyebabkan mereka menggunakan 
lukisan Eugene Delacroix sebagai basis sampul album mereka ("Viva La Vida," n.d.).

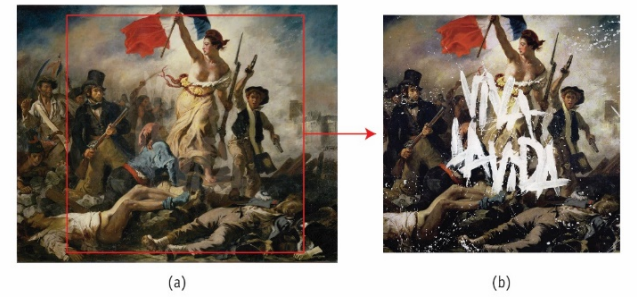

Gambar 1 (a) Lukisan 'Liberty Leading the People' karya Eugene Delacroix yang ditandakan bagian mana yang dipotong untuk (b) Desain Sampul 'Viva La Vida' karya Mark Tappin dan Simon Gofton Sumber: Dokumentasi Penulis, 2019

Salah satu aspek menarik pada karya sampul album 'Viva La Vida' adalah bagaimana karya tersebut mampu menggunakan referensireferensi eksternal untuk membantu membangun makna karya. Ketika kita melihat karya tersebut tanpa adanya pemahaman atau konteks, kita dapat menikmati karya tersebut sebagai sebuah karya visual yang menarik (seimbang, menyatu, unik); namun ketika kita paham ada rujukan visual dan juga tekstual yang berada diluar karya tersebut, maka ada nilai lain yang muncul ketika melihat karya tersebut. Pemahaman ini dapat dikenali sebagai intertekstualitas, sebuah istilah yang diperkenalkan oleh Julia Kristeva pada tahun 1966 (Zantides, 2016). Pemahaman mengenai intertekstualitas akan dibahas lebih lanjut pada sub-bab selanjutnya.

\section{LANDASAN TEORITIS}

\section{Desain Grafis}

Desain grafis adalah sebuah bentuk atau jenis komunikasi visual yang digunakan untuk menkomunikasikan suatu pesan, kesan dan juga informasi kepada audiens; cara desain grafis melakukan komunikasi tersebut adalah dengan membuat, memilih dan juga mengelompokkan elemen-elemen visual (Landa, 2011). Desain grafis juga dinilai sebuah bentuk seni rupa yang kreatif, dimana beragam aspek-aspek visual merupakan bidang yang diolah oleh desainer grafis (Ambrose \& Harris, 2009).

Dua elemen primer dalam desain grafis adalah image dan type, dimana pemisahan antara keduanya dilakukan karena cara kerja keduanya yang berbeda (Hananto, 2019; Skolos \& Wedell, 2011). Elemen type adalah elemen tulisan, dimana audiens dapat memaknai tulisan karena adanya pengetahuan dan juga kesepakatan untuk dapat memahami bentuk tersebut menjadi sesuatu yang dapat dibaca. Elemen image adalah elemen gambar, dimana audiens mampu memaknai gambar karena adanya pengalaman empirik dari apa yang digambarkan sebelumnya. Sebagai contoh, ketika seseorang melihat gambar buah pisang, orang tersebut dapat mengenali rasa, membayangkan tekstur dan juga menilai 
apakah pisang tersebut sudah matang atau belum karena ia pernah 'mengalami' pisang tersebut dengan cara memakannya. Berbeda dengan membaca tulisan 'pisang' yang mungkin hanya merujuk kesebuah pengertian namun tidak dapat memberikan gambaran lebih.

Pemisahan dari kedua elemen ini membuka pemahaman baru mengenai desain grafis, dimana seorang desainer grafis dapat membentuk pesan dengan menentukan cara visualisasi dari elemen-elemen visual yang digunakan. Gambar dan tulisan dapat dilihat dalam waktu bersamaan, namun otak kita melihatnya sebagai dua entitas berbeda (Skolos \& Wedell, 2011). Dengan demikian, sesuatu yang kita pilih untuk visualisasikan dengan gambar dan dengan tulisan dapat memiliki arti yang berbeda.

\section{Intertekstualitas}

Intertekstualitas merujuk kepada sebuah keberadaan sebuah teks secara literal didalam teks lain (Khosravishakib, 2012). Teks disini dipahami sebagai segala sesuatu yang dapat dibaca atau dimaknai. Pandangan mengenai intertekstualitas juga menjelaskan bagaimana makna dapat terbangun atau dimengerti dalam relasi dengan teks-teks lain yang telah ada terlebih dahulu (Zantides, 2016). Bahkan pandangan lebih radikal mengenai intertekstualitas mengungkapkan bahwa tidak ada teks yang berdiri sendiri; bahwa semua teks pasti merujuk teks-teks lain (Damirchi Loo, 2018).

Pandangan ini sejalan dengan pandangan bahwa obyek desain grafis sendiri merujuk bahwa kedua elemen desain, image dan type, sama-sama dapat menghadirkan makna dengan membutuhkan teks lain: konvensi dan juga pengalaman empirik. Type atau tulisan merupakan sebuah teks yang dapat dimengerti karena adanya pandangan atau konvensi eksternal (Hananto, Syarief, \& Udjianto, 2018); sedangkan image dapat dikenali karena adanya pengalaman empirik.

\section{METODE}

Penelitian atau kajian ini dilakukan dengan pendekatan kualitatif, yaitu melakukan artifact analysis dan juga literature review. Artifact analysis adalah sebuah kajian atau observasi secara sistematis kepada material, estetik dan juga interaktif dari sebuah obyek yang dapat mendukung pemahaman dari peneliti akan bentuk, dan konteks karya tersebut (Martin \& Hanington, 2012). Artifact analysis dilakukan untuk mencacah elemen desain dan visual dari karya yang dikaji. Setelah melalui tahapan ini, peneliti melanjutkan dengan proses literature review; yang merupakan proses pengumpulan data sekunder 
dengan cara melihat literatur-literatur yang dapat mendukung penelitian (Martin \& Hanington, 2012). Tahapan literature review digunakan untuk mendapatkan kerangka teori untuk membantu menkaji karya dan juga mendapatkan referensi atau rujukan teks ketika membaca karya desain guna mendapatkan makna-makna baru yang sebelumnya tidak muncul ketika menkaji karya tersebut secara independen dan internal.

\section{PEMBAHASAN}

\section{Pembahasan Formal Karya}

Secara sederhana, desain sampul album 'Viva La Vida' merupakan lukisan 'Liberty Leading the People' karya Eugene Delacroix dengan tulisan tangan "Viva La Vida" berwarna putih yang ditulis menggunakan kuas. Lukisan 'Liberty Leading the People' sendiri adalah lukisan yang menggambarkan kerumunan massa yang mengikuti seorang wanita dengan baju yang bagian dadanya sedikit terkoyak. Wanita tersebut memegang bendera berwarna merah, putih dan biru di tangan kanannya, dan memegang senapan laras panjang dengan bayonet pada tangan kirinya. Kerumunan massa itu juga tengah berdiri diantara tubuh orang-orang yang meninggal, dimana sebagian orang meninggal tersebut mengenakan baju tentara. Pada desain sampul album 'Viva La Vida' pada tengah-tengah cuplikan lukisan tersebut tertera tulisan putih yang bertuliskan "Viva La Vida". Selain itu pada tepian desain sampul tersebut, terdapat percikan cat berwarna putih. Penjelasan pada paragraf selanjutnya akan membahas lebih mendalam mengenai aspek-aspek visual tersebut.

Secara umum, terdapat dua elemen desain yang dominan terlihat dalam karya sampul album tersebut, yaitu type dan image. Type mengacu pada elemen huruf, dan pembahasan mengenai type pastinya akan sedikit banyak membahas mengenai tipografi; Type dalam sampul album band Coldplay ini adalah tulisan 'Viva La Vida' yang dibuat dengan menggunakan kuas dan berwarna putih. Image adalah elemen gambar, yang bisa merupakan fotografi ataupun ilustrasi, atau cuplikan lukisan 'Liberty Leading the People' dalam kasus desain sampul album 'Viva La Vida' ini. Relasi antara kedua elemen tersebut, menurut Nancy Skolos \& Thomas Wedell, adalah separation; dimana kedua elemen tersebut berdiri sendiri tanpa interaksi atau mempengaruhi satu sama yang lain (Skolos \& Wedell, 2011). Teknik separation yang tampak dalam karya tersebut adalah layering, dimana type diletakkan diatas image dan keduanya terlihat dengan cukup jelas (Skolos \& Wedell, 2011). Separation menciptakan struktur dan hirarki yang baik pada desain, dan memudahkan penyajian informasi dengan 
lebih jelas. Hal ini terlihat bagaimana type, yang merupakan nama album tersebut, memiliki warna putih dan terlihat kontras dari image yang menjadi latar dari desain tersebut.

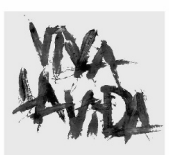

type

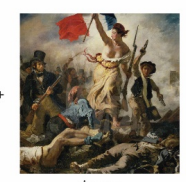

image

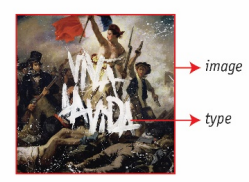

Gambar 2 Dua Elemen Desain Grafis yang Menyusun Desain Sampul 'Viva La Vida'

Sumber: Dokumentasi Penulis, 2019

Walaupun elemen type dan image tersebut hadir secara terpisah, namun kedua elemen tersebut memiliki karakteristik yang serupa sekaligus kontras. Hal tersebut membuat desain sampul album tersebut memiliki kesatuan yang baik. Elemen type yang merupakan kaligrafi, dieksekusi dengan karakter garis jagged dan brushstrokes yang terlihat splattered dan dribbled menghasilkan efek yang dinamis. Karakteristik serupa yang ditemukan adalah penggunaan medium cat pada image, namun karakteristik pada image terlihat berbeda dengan type, dimana image penuh dengan garis freehand dengan brushstrokes yang delicate dan juga blurred brushstrokes. Hal ini menimbulkan kesan yang lebih halus dan stabil, dan akhirnya membantu menghasilkan kontras terhadap type.

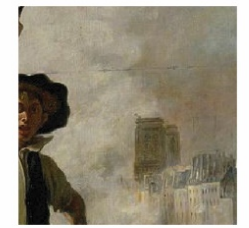

(a)

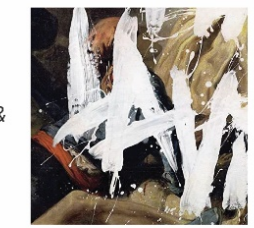

(b)

\section{Gambar 3 (a) Image yang delicate dan blurred, (b) Type yang Splattered dan dribbled. \\ Sumber: Dokumentasi Penulis, 2019}

Walaupun terlihat berbeda dan terpisah, namun posisi type yang berada di tengahtengah image seolah menjajah image. Hal ini memberikan penekanan lebih dan fokus pada pesan dari type dibandingkan adegan yang diilustrasikan oleh image. "Viva La Vida" sendiri merupakan bahasa Spanyol dari "jalani hidup", dan pesan tersebut yang membelakangi ilustrasi yang tampak seperti peperangan, yang melibatkan Prancis, dimana hidup dan mati adalah keberadaan yang kontras dan drastis ditemui. Hal ini seolah menekankan bahwa dalam situasi tersebut, peperangan perlu dijalani sebagai bagian dari hidup itu. "Viva La Vida" seolah menjadi teriakan perang yang mendorong sosok-sosok yang mempertaruhkan nyawa mereka dalam situasi tersebut. Dengan membaca type kemudian image, type pada karya desain sampul album ini seolah-olah memberikan lebih dari sekedar nama album, namun memberikan pesan tersendiri yang membawa makna baru pada ilustrasi tersebut. 


\section{Pembahasan Intertekstualitas}

Pertanyaan yang sering kali ditanyakan ketika membahas mengenai desain sampul album Coldplay ini terkadang bukan mengenai pesan ataupun aspek-aspek formal dari desain itu sendiri, melainkan "apakah desain tersebut boleh/legal?". Jawaban sederhana dari hal tersebut adalah boleh, mengingat aturan mengenai copyright sendiri mengatakan bahwa usia dari sebuah copyright adalah sepanjang hidup sang seniman atau desainer ditambah 70 tahun ("What is Copyright?," n.d.). Pelukis 'Liberty Leading the People' sendiri, Eugene Delacroix, meninggal pada tahun 1863, dan berdasarkan aturan mengenai hak cipta, karya Eugene Delacroix sudah bebas dimodifikasi dan digunakan sejak tahun $1933(1863+70)$ ("Eugène Delacroix," 2017). Penggunaan lukisan 'Liberty Leading the People' sebagai basis dalam desain 'Viva La Vida' sendiri merupakan sebuah homage terhadap Eugene Delacroix melihat natur penggunaannya yang tidak merusak atau memparodikan karyanya. Saat penggarapan album 'Viva La Vida', Coldplay menemukan lukisan Eugene Delacroix ini menunjukan optimisme, dan hal ini sejalan dengan pesan dan citra yang ingin dibawakan oleh Coldplay.

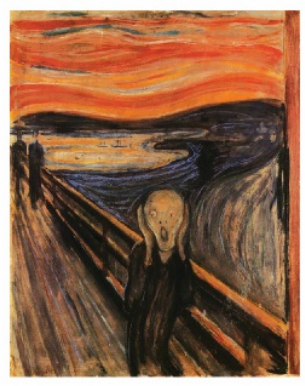

(a)

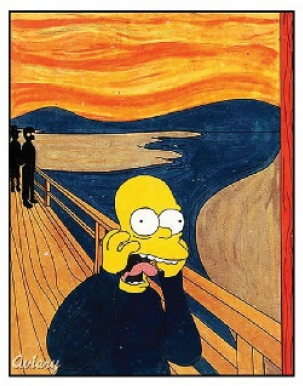

(b)
Gambar 4 Contoh Parodi (a) 'The Scream' oleh Edward Munch, (b) Parodi Karya 'The Scream', oleh Seniman Meowza

Sumber: bitrebels.com, 2019

Hal menarik lain terkait homage yang dilakukan oleh Coldplay pada sampul albumnya adalah menggunakan judul 'Viva La Vida', yang merupakan judul lukisan oleh Frida Kahlo, yang melukiskan buah semangka dengan tulisan "Viva La Vida". Chris Martin menjelaskan bahwa Frida Kahlo mengalami banyak hal yang tidak mengenakan dalam hidupnya, namun di dalam rumahnya, ia memiliki sebuah lukisan semangka besar dengan tulisan "Viva La Vida” tersebut; hal ini, bagi Chris Martin, menunjukkan keberanian dan semangat Frida Kahlo yang akhirnya menginspirasi Chris Martin untuk menamai album mereka 'Viva La Vida' (Shabi, 2015). Fakta ini menjelaskan mengapa bahasa Spanyol ("Viva La Vida") pada lukisan Prancis ('Liberty Leading the People') digunakan sebagai ide sampul album Coldplay. 


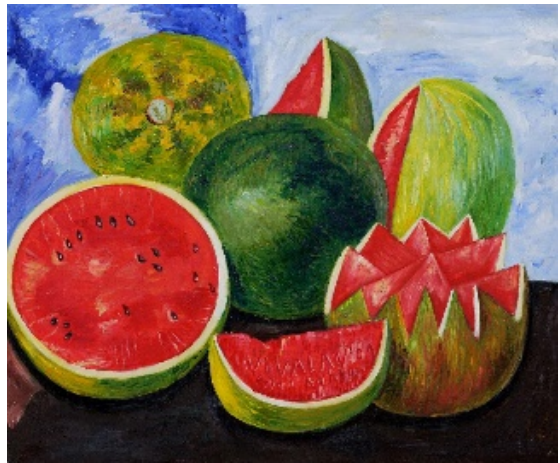

Gambar 5 Lukisan 'Viva La Vida' oleh Frida Kahlo Sumber: artsandculture.google.com

Ketika kita melihat desain sampul album 'Viva La Vida', kita dapat menginterpretasikan beberapa hal mengenai karya tersebut, namun ketika kita memahami latar dari pembuatan album tersebut, atau mengetahui fakta-fakta mengenai lukisan 'Liberty Leading the People' ataupun 'Viva La Vida', kita menemukan satu lapisan makna yang muncul dari pemahaman tersebut. Karya yang mencoba mengkomunikasikan perspektif positif akan hidup ini digambarkan dengan alegori. Alegori sendiri adalah representasi yang menggunakan simbol (Meggs, 1992), sebuah tanda yang maknanya dikenali secara konvensional (Noble \& Bestley, 2005). Disini, kedua lukisan tersebut adalah sebuah simbol, dikarenakan pemaknaan dari kedua lukisan tersebut muncul karena adanya konvensi. Oleh karena itu, dengan memahami kedua simbol tersebut (lukisan Delacroix \& Kahlo), seorang audiens dapat menggali satu tingkatan lebih mendalam mengenai karya sampul album 'Viva La Vida'.
Berbicara mengenai alegori, lukisan 'Liberty Leading the People' sendiri merupakan lukisan yang penuh makna. Lukisan tersebut tidak hanya menggambarkan suasana perang atau revolusi Prancis secara harafiah saja; lukisan tersebut menyelipkan nilai-nilai dengan mempersonifikasi kebebasan (liberty) kepada sebuah sosok perempuan berbaju kuning yang bajunya terkoyak. Baju terkoyak sang perempuan juga mencoba mengindikasikan bahwa sosok perempuan tersebut dilukiskan bak dewi-dewi dalam mitologi Yunani, perujukkan seperti ini juga merupakan sebuah alegori (Bouabdellah \& Dorbani, n.d.). Pengetahuan akan hal ini membukakan satu lapisan makna yang lebih dalam dari sebelumnya.

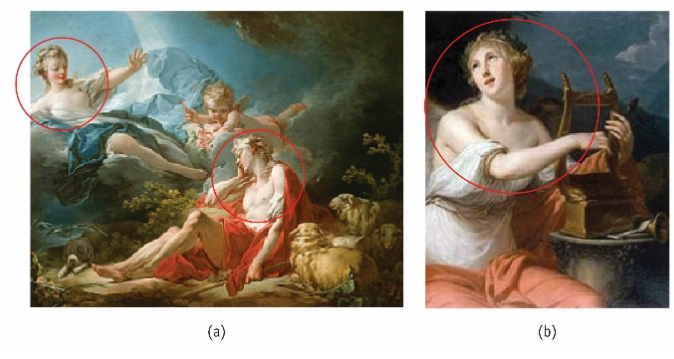

Gambar 6 (a) Lukisan yang Menggambarkan Diana dan Endymion karya Jean-Honore Fragonard, (b) Lukisan yang Menggambarkan Muses. Sumber: Dokumentasi Pribadi, 2019

\section{KESIMPULAN}

Pada akhirnya, desain sampul album keempat Coldplay ini dapat mengajari kita banyak hal dalam melihat karya desain grafis. Album yang mengantar Coldplay ke fase yang 
lebih berwarna dan optimistik ini tidak hanya direpresentasikan melalui lagu-lagu yang lebih beragam, namun juga dengan sebuah visual yang kaya akan pesan-pesan positif. Menurut penulis, bukan sebuah kesengajaan Coldplay dan para desainernya menggunakan lukisan Eugene Delacroix sebagai image dari sampul album mereka, dan bukan sebuah hal yang tidak dipikirkan ketika mereka menuliskan "Viva La Vida" dengan menggunakan cat putih itu. Memahami dan mengenali akan konteks dari sebuah desain mampu membuat kita menggali konten, namun perlu diingat hal ini tidak berlaku semata-mata ketika menafsirkan sebuah karya seni atau karya desain. Kita dapat menggunakan paradigma tersebut ketika merancang sebuah karya desain. Menyadari bahwa desain adalah sebuah objek yang tidak lepas dari dunia ini membuat kita sadar bahwa setiap elemen yang muncul memiliki potensi untuk menjadi kaya akan makna.

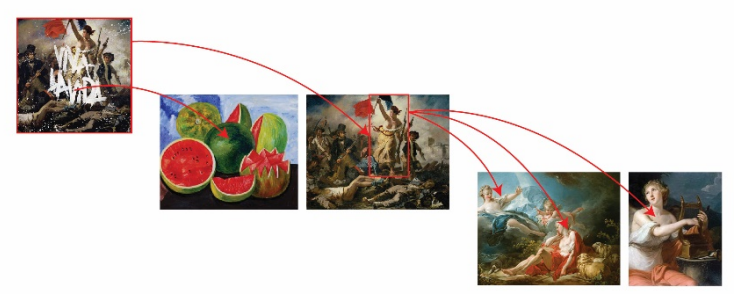

Gambar 7 Skema yang Menggambarkan Relasi Referensi \& Rujukan dari Karya yang dibahas. Sumber: Dokumentasi Pribadi, 2019

Dengan melihat hasil kajian ini, penulis menyimpulkan bahwa nilai dari karya sampul album 'Viva La Vida' memiliki nilai lebih ketika dilihat dengan perspektif yang lebih luas. Berdasarkan pemahaman intertekstualitas, penulis menilai bahwa hal apa yang penulis simpulkan dari kajian sampul 'Viva La Vida' ini tentu juga dapat ditemukan dalam karya-karya lain juga. Hal ini yang membuat penulis mendorong bahwa sebuah kajian karya membutuhkan literature review mencari teksteks lain yang memperkaya pemahaman dari sebuah desain. Dengan demikian kajian yang dilakukan dapat menjadi lebih komprehensif dengan adanya rujukan atau referensi dari teks lain.

Dengan pemahaman bahwa intertekstualitas tidak bisa dilepaskan, penulis juga mendorong perancangan yang lebih koheren dengan mempertimbangkan konteks dan juga pengetahuan umum guna memperkaya makna dari sebuah desain. Dengan memilih artefak-artefak atau tandatanda yang telah dikenali, maka desainer dapat mengemas beragam makna (baik secara luas maupun mendalam) dalam sebuah karya visual.

\section{DAFTAR PUSTAKA}

[1] Ambrose, G., \& Harris, P. (2009). The Fundamentals of Graphic Design. Case Postale: AVA Publishing.

[2] Bouabdellah, M., \& Dorbani. (n.d.). July 28: Liberty Leading the People. Retrieved September 6, 2019, from Louvre.fr website: 
https://www.louvre.fr/en/oeuvrenotices/july-28-liberty-leading-people

[3] Damirchi Loo, L. (2018). The Influence of Intertextuality on Aesthetic Principles in Postmodernist Painting and Architecture. Civil Engineering Journal, 4(6), 1426. https://doi.org/10.28991/cej-0309183

[4] Eugène Delacroix. (2017). Retrieved September 6, 2019, from Theartstory.org website:

https://www.theartstory.org/artist/delacro ix-eugene/

[5] Gofton, T. (2009). Viva La Vida Sketchbook. Retrieved September 6, 2019, from Coldplaying.com website: https://coldplaying.com/forum/index.php ?threads/viva-la-vida-sketchbook-tappingofton.63933/

[6] Hananto, B. A. (2019). Identitas Visual Digital Brand Dalam Sosial Media. Seminar Nasional Desain Dan Arsitektur (SENADA) 2019, 2, 56-61.

[7] Hananto, B. A., Syarief, A., \& Udjianto, A. N. (2018). Pengembangan Motif Batik Semarangan Menggunakan Tipografi Sebagai Gagasan Visual. Jurnal Seni \& Reka Rancang, 1(1), 1-18.

[8] Khosravishakib, M. (2012). Inevitability of arts from intertextuality. Frontiers of Language and Teaching, 3, 183-189. https://doi.org/10.5897/IJEL11.101

[9] Landa, R. (2011). Graphic Design Solutions (4th ed.). Boston: Wadsworth Cengage Learning.

[10] Martin, B., \& Hanington, B. (2012). Universal Methods of Design. Massachusetts: Rockport Publisher.

[11] Meggs, P. B. (1992). Type and Image: The Language of Graphic Design. New York: John Wiley \& Sons.

[12] Noble, I., \& Bestley, R. (2005). Visual Research: An Introduction to Research Methodologies in Graphic Design. Switzerland: AVA Publishing.

[13] Shabi, K. (2015). Viva la Vida Meaning: Coldplay, Delacroix \& Frida Kahlo
Watermelons. Retrieved September 6, 2019, from Legomenon.com website: http://legomenon.com/viva-la-vidameaning-coldplay-delacroix-fridakahlo.html

[14] Skolos, N., \& Wedell, T. (2011). Type, Image, Message: A Graphic Design Layout Workshop. Massachusetts: Rockport.

[15] Viva La Vida. (n.d.). Retrieved September 6, 2019, from songfacts.com website: https://www.songfacts.com/facts/coldplay /viva-la-vida

[16] Viva La Vida Biography. (2008). Retrieved September 6, 2019, from Coldplay.com website:

https://timeline.coldplay.com/article/vivala-vida-biography/

[17] What is Copyright? (n.d.). Retrieved September 6, 2019, from artslaw.com.au website:

https://www.artslaw.com.au/legal/rawlaw/what-is-copyright/

[18] Zantides, E. (2016). Visual metaphors in communication: Intertextual semiosis and déjà vu in print advertising. Romanian Journal of Communication and Public Relations, 18(3), 65-74. 